\title{
Positive Psychology and the Qur'an: A Comparative Study of the \\ Constructs of Hope, Resilience, and Forgiveness
}

\author{
Iranian Evolutionary and Educational \\ Psychology Journal \\ September 2020: 208-224 \\ (C) University of Hormozgan Publication 2020 \\ DOI: 10.29252/ieepj.2.3.208 \\ http://ieepj.hormozgan.ac.ir
}

\section{Abdolah Foroozanfar}

\begin{abstract}
Hope, resilience and forgiveness are among the topics that have been considered both in the field of psychology and in the field of religion. All moral religions have sought to create and strengthen hope, resilience and forgiveness in human beings. In this article, an attempt has been made to examine the commonalities and differences between these constructs from the perspective of the Quran and positive psychology. Therefore, using library resources and descriptive-analytical method, the statements obtained from Quranic verses on the subject of hope, resilience and forgiveness have been examined. Identifying the foundations, effects and consequences of these structures, as well as the solutions offered to create and increase these features from the perspective of positive psychology and the Quran an have been among the objectives of this article. One of the most important findings of the research is that the basis of these characteristics in the Quran an is belief in God, resurrection and the nature of human perfectionism and in positive psychology, materialism, semantics and generally the issues of this world and individual. Achieving the desired perfection that is the goal of both views in the Quran is to achieve the nearness of God and the status of the expected divine caliphate and in positive psychology, success in life and having positive emotions. It seems that when a person suffers from a lack of meaning in life and does not satisfy the affairs of his material life, only believing in the origin of existence and hope for his infinite mercy and meeting.
\end{abstract}

Keywords: Qur'an, Positive Psychology, Hope, Resilience, Forgiveness

\section{Introduction}

Although the positive psychology movement officially started a decade ago, the theories and ideas of positive-oriented psychology are not completely new and go back to decades ago and even to the beginnings of psychological science. Perhaps the first opine on positive psychology belongs William James, who introduced the concept of a healthy mindedness years ago (Joseph \& Linley, 2006). Other manifestations of positive psychology can be found in the schools of the humanism of Maslow and Rogers. Maslow has approached positivist psychology with the concept of self-actualization and Rogers with stress on perfection and happiness. Nonetheless, the rejection of positive psychology - as is known today - can be traced back to 1998. It was when Martin Seligman, the father of positive psychology and then president of the American Psychological Association, introduced this concept. By introducing this concept, Seligman stated that for half a century, psychology had examined only one subject, mental illness (Fowler, Seligman, \& Koocher, 1999). Seligman stresses that psychologists should pay attention to the main missions of psychology, which is helping others to give birth, identify and nurture individuals' talents, and expand the definition of psychology to include positive mental 
health, rather than the diseases (Csikszentmihalyi, Latter, \& Weinkauff Duranso, 2017). Many papers and books were published on positive psychology following Seligman's work. The Journal of Positive Psychology was established with many conferences and seminars were held on it.

Sheldon and King (2001) consider positive psychology as the study of the abilities and superiorities of the laypeople. This description of positive psychology refers to the study of positive human functions with a focus on the conditions and processes affecting those functions (Harzer, 2016). Csikszentmihalyi and Seligman (2000), who consider it a branch of psychology that emphasizes valuable mental experiences, provide a more precise definition of positive psychology. The experiences like psychological well-being, resilience, commitment, and satisfaction (related to the past), hope and optimism (related to the future), and the flow of forgiveness, and happiness (related to the present) are of this class. According to this definition, positive psychology is related not only to individual growth and development but also to the similar optimization of group traits and characteristics: a goal that focuses on three stages of life, the past, the present, and the future. According to the system of positive psychology, the individual role of a psychologist is not to reduce or alleviate anxiety, but to help facilitate the well-being of individuals by emphasizing the concepts of prevention (Joseph \& Linley, 2006).

Concepts like psychological well-being, mental happiness (Diener \& Lucas, 2000), the theory of constructing and spreading positive emotions (Fredrickson, 2003), awareness (Bishop et al., 2004), spirituality (Lopez, Pedrotti, \& Snyder, 2007), self-efficacy (Bandura, 1997), learned optimism (Seligman, 2006), mental health (Buchanan \& Bardi, 2010), and hope (C Richard Snyder et al., 2002) are of the concepts in positive psychology. Mental health institutions, hospitals, and schools have used interventions based on the principles of positive psychology. In the field of mental health, apart from positive-centered approaches to individual therapy, positive psychology strategies have a special effect on group therapies. Focus group therapy has been effective in setting goals and increasing hope in a wide range of therapeutic and educational situations (Samavi, Najarpourian, \& Javdan, 2019). Besides reducing anxiety and depression, it has increased hope as well (James \& Roby, 2019).

Many of the issues and topics addressed in positive psychology have been examined in the Holy Quran as well. The Holy Quran has examined these issues through the lens of beliefs, considering them effective in achieving human perfection. Still, positive psychology has considered them from materialism or semantics perspectives, considering them effective in the treatment of many mental diseases and disorders.

Hope, resilience, and forgiveness are of the topics considered in both the Quran and positive psychology and have been recognized as effective in achieving the desired perfection of human beings. As positive psychology has dealt with these constructs from the perspective of psychotherapy and has paid attention to the ways of creating and increasing these constructs in clients for the treatment of some of their mental disorders; therefore, these constructs have been examined in the Quran from this aspect and not the others. However, the Quran deals with these issues extensively and from various angles, and each of them deserves an independent study. The study intends to examine these three constructs of psychology from the perspective of the Holy Quran and positive psychology and answer the following questions:

1- What are the commonalities and differences between the Holy Quran and positive psychology in the three constructs of hope, resilience, and forgiveness?

2- What are the solutions of the Quran and positive psychology in creating and increasing these three con- 
structs?

\section{Hope construct in positive psychology}

From the second half of the twentieth century, having a hopeful view towards life, as one of the most effective treatments for some mental illnesses like despair and depression, has attracted the attention of Western psychologists and eventually led to Charles Richard Snyder's theory of hope (C Richard Snyder, 2002). Other researchers and experts followed this construct, and some theories were presented, but since Snyder's theory is more comprehensive and is silent about spirituality and religious approach, the study has considered it as a criterion of the theory of hope in psychology (JahangiriZadeh \& Khodabakhshi Koolaee, 2016). To Snyder, hope is the perceived capacity to produce paths to desirable goals and the perceived motivation to move in those paths (C Richard Snyder, 2002). Thus, hope means positive expectations to reach goals. This positive expectation has two dimensions, Agency and Pathway (C Richard Snyder, 2002).

According to the above definition, hope theory is a cognitive process that has emotional consequences and the individuals actively strive to achieve their goals through it. In other words, hope is a process in which a person sets his goals, creates solutions to achieve them, and creates the necessary motivation to implement these strategies and maintains them along the path (C Richard Snyder, 2002).

According to Snyder's theory of hope, the dimensions of hope are goal thinking, agency thinking, and pathway thinking, which interact. As the theory of hope is based on the significance and necessity of goals, the goal is one of the key dimensions of this theory (Feldman, Rand, \& Kahle-Wrobleski, 2009). Almost everything a person does is to reach a goal. Goals are the driving force of any behavior and can have a wide range (Feldman et al., 2009). Goals are the main source of excitement. Positive emotion is the result of achieving or approaching a goal, whereas negative emotion is caused by failure to achieve a goal or the idea of moving away from it (C Richard Snyder, 2002). According to this theory, the best goals are those that increase a person's motivation and are sustainable: goals precisely defined have moderate difficulty and will occur soon (Feldman et al., 2009).

Pathway thinking is a person has perceived ability to identify and create paths to achieve a goal (Charles Richard Snyder, 1994). In other words, as some plans may fail, those with great hopes consider several avenues to deal with potential obstacles (Charles Richard Snyder, 1994). Pathway thinking is the next dimension of motivation to move a person in the paths intended to achieve the goal. Charles Richard Snyder (1994) defined agent thinking not only as goal-focused mental energy but also as a sense of determination to achieve a goal. To him, this kind of goal-focused motivation shows itself in phrases like "I can do it," "I will achieve it," and so on (Charles Richard Snyder, 1994).

Hope therapy based on hope theory is designed to increase hopeful thinking and enrich activities related to goal pursuit with two stages: the stage of instilling hope, which seeks finding-hope and hope banding, and the stage of increasing hope, followed by hope-enhancing and hope-reminding. In instilling hope stage, the therapist helps the clients to find the hope they have experienced in the past by defining their life story, and thus, the therapist becomes aware of how to create hope in the person and the destructive thoughts and behaviors of hope (Bahari, 2011). Moreover, the therapist models hopeful thinking and behavior and increases the thinking of the agent and the pathway in the clients, and the motivation of the clients and the pathways to achieve the goal can be increased through this (Feldman et al., 2009). In the hope-increasing phase, the 
therapist enriches the hope of his clients by providing solutions that lead to goal creation, development of the pathway and increase of the agency in the individual (Bahari, 2011) and then encourages the clients to increase hope by themselves by recognizing the thoughts of the target and the thoughts of the obstacle. The key element of the hope retention process is the ability to recognize target and obstacle thoughts (Bahari, 2011).

\section{Hope construct in the Quran}

Hope and hopefulness towards the future have been stated in the Holy Quran many times and in different ways, and its foundation is in relation to God Almighty. As hope is for human evolution and human evolution in the Quran, is towards the position of the divine caliphate:

"اوَ إذ قالَ ربك للملائكةُ انى جاعل فى الارض خليفهُ)"

"I will create a vicegerent on earth." Baqara, 30

Hope is also in line with the manifestation of the divine attributes institutionalized in human existence. However, the concept of hope (in its positive and negative layers) can be pursued in the Holy Quran through keywords such as "Raja" (expecting something popular and desirable that most of its causes are realized), "Tamaa" (the desire of the soul out of greed and the intense desire to something out of human reach), "Amal" (a long-awaited desire) and "Tamanni" (the desire to achieve something along with appreciation and measurement). Among the terms stated, it is only in the word "Raja" that the hopeful person works and strives to reach his hope and provides the means to achieve the beloved thing, whereas the only hope is to achieve the beloved thing without preparing himself to achieve it in the other three words.

Examining the verses containing the words of hope in the Quran shows that hope has a positive and pleasing nature; nonetheless, the factors that create it, as well as its disruptive barriers, may be true or false. Accordingly, hope can be divided into two types:

A- Desired, sincere and true hope: This type is related to matters that are in the direction of divine pleasure and in harmony with the reality of human existence and is presented in two ways in the Quran: hope for the Hereafter and enjoying the divine mercy that most believers hope for and the other is the hope of meeting God, which is hoped for by special believers and perfect human beings (Kahf / 110).

B. Undesirable, false and virtual hope: This type is related to matters where divine pleasure is not considered and is the result of the temptations of the soul or the instincts of Satan: as it is stated in the Quran from the language of Satan: "و "لأُمنينهم" that is I will make them have longings (Nisa / 119).

The concept of hope in the Holy Quran can be pursued in two axes of belief and behavior because the Quran, in addition to expressing doctrinal and individual solutions to induce hope, has also provided behavioral and social solutions to strengthen and increase it. The purpose of belief solutions is cognitive methods to increase and strengthen hope in human, which refers to the individual's view and belief in existence, the beginning and end of the world and the role of prophets and saints, and on the other hand, its effect in increasing or evaluates the decrease of honest and true hope in a person. Belief in the oneness of God (God-centeredness) causes man to constantly look to a single source of refuge instead of thinking of various factors influencing his life and fearing them or hoping for them (Tauba/ 118). It is through the channel of monotheism that man understands the remembrance of God calms the issue of hoping in God and his heart:

|(الذين آمنوا و تطمئن قلوبهم بذكر اللها....

"Those who believe, and whose hearts find satisfaction in the remembrance of Allah" (Rad, 28). Regarding this, many verses of the Quran sow the seeds of hope in man in the shadow of belief in God and place true 
hope in him alone.

On the other hand, God has strengthened the spirit of hope in other human beings by expressing the lives of the prophets. As Prophet Yusuf finally returned to his father (Yusuf / 100) and the fire of Nimrodians turned into a flower garden by the grace of God (Anbia / 69). The hope of the Quran is not limited to this worldly life but also the Hereafter (Tauba / 21 and 22). Belief in the resurrection burns the roots of despair and hopelessness and gives man hope that none of his good deeds will be erased from the face of the universe, and his failures will not go unanswered in this world. The man who believes in the resurrection believes that life is not limited to this material world, but that man has a life after death, and there he achieves many of his proper desires and aspirations. The believer hopes that he will enjoy the blessings of God in the next world as well. The Quran introduces the Hereafter as eternal life and eternal life and eternal bliss as well (Ghafar / 39) and considers comfort, tranquility, and absolute security as exclusive to it (An'am / 127).

Behavioral strategies are the practical approaches to increase and strengthen hope in a person; the solutions related to human behavior and performance to increase true and sincere hope. The most critical behavioral strategies of the Quran in the individual sphere are a- "Tahajjud" and vigil: In Surah Zumar, God has called the vigils hopeful and introduced the night and night vigil prayer as hopeful factors:

(أ مَّن هو قانتُ ءاناء الليل ساجداً و قائماً يَحذَرُ الآخرهُ و يرجوا رحمةُ ربهله

"Is one who worships devoutly during the hour of the night prostrating himself or standing [in adoration], who takes heed of the Hereafter, and who places his hope in the Mercy of his Lord" Zumar, 9

B- Fear of God (hope-inspiring fear): God emphasizes in many verses that man should only be afraid of him and this fear should always be present in him.

(فلاتخافوهم و خافون إن كنتم مؤمنين"

"It is only the Evil One that suggests to you the fear of his votaries: Be ye not afraid of them, but fear Me, if ye have Faith.” Al-Imran, 175

This is because this fear prevents him from doing bad deeds and forces him to do good deeds if it penetrates deep into the human. Indeed, it is this hope-creating fear that hope-bands the foundations of hope in human. Thus, in many verses related to hope, this type of fear is used alongside the word "Tamaa," greed (Araaf / 57). C- "Tauba" repentance to God: Repentance to God is the way that God has set for humans to avoid despair:

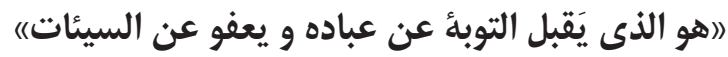

[Pharaoh] said to those around, "Did ye not listen [to what he says]?" (Shuraa / 25)

Therefore, a sinful person who has lost hope by sinning can regain his peace and hope-binds by repenting: "(ايَهدى اليه مَن أنابَ الذين آمنوا و تطمئن قلوبههم بذكر الله)

"Those who believe, and whose hearts find satisfaction in the remembrance of Allah: for without doubt in the remembrance of Allah do hearts find satisfaction.” Rad, 27-28

D- Migration and jihad for God: According to the verse:

״إن الذين آمنوا و الذين هاجرواو جاهَدوا فى سبيل الله اولئك يَرجون رحمة الله) "

"Those who believed and those who suffered exile and fought [and strove and struggled] in the path of Allah,- they have the hope of the Mercy of Allah: And Allah is Oft-forgiving, Most Merciful." Baqara, 218

Hope for God's grace and mercy is conditional on faith, migration and jihad.

In the social sphere, two of the most important behavioral strategies of the Quran to increase and strengthen hope are A- "Ehsan" virtuosity: According to the Quran, a virtuous person hopes for the grace and care of 
God:

(إن رحمتَ الله قريبُ من المحسنين ....

"for the Mercy of Allah is [always]

near to those who do good." Araf, 56

B- Forgiveness: forgiveness is of the examples of benevolence:

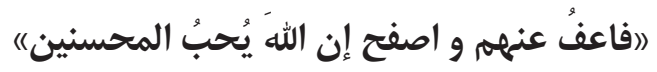

"I am with you: If ye

(but) establish regular Prayers, practice regular Charity, believe in My

apostles, honor and assist them" Maida, 13

The mercy of God, which the believers are always waiting for, and which they long to attain (Baqara / 218), is close to the virtuous (Araf / 56). Therefore, the believers and those who hope for divine mercy can achieve their hope and desire through the forgiveness of others, which is to receive divine mercy and achieve true peace.

The Holy Quran considers desirable goals that always lead a person to spirituality and God Almighty, so that besides increasing a person's hope to achieve his goal, make him committed to worldly life and teach him the path to achieve these goals through the world and he should try to prepare himself to achieve these great goals by performing righteous and God-pleasing deeds:

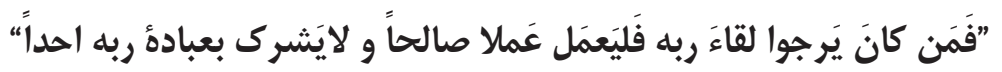

"Whomever expects to meet his Lord, let him work righteousness, and, in the worship of his Lord, admit no one as partner." Kahf, 110

Thus, goal thinking from the perspective of the Holy Quran means choosing goals that, while putting a person on the path of evolution, create a commitment to the life of the world and create hope and peace in the light of preserving divine and human principles and values. Pathway thinking is also all the efforts of man to achieve his worldly and otherworldly goals by observing piety and sincerity in doing things (Kahf / 110). Thus, doing all that pleases God and his Prophet as well as refraining from committing sins and anything that causes the wrath of God and his Prophet (Tauba / 71) is considered as a pathway from the perspective of the Holy Quran. The mental energy needed to realize the goal, complete faith and belief in God, is another dimension of hope in the Holy Quran, which can be referred to as agency thinking. When complete faith is established in the human heart, besides paying attention to the worship of God (increasing individual motivation and hope), it turns to society to meet the needs of society and compensate for shortcomings (increasing social motivation and hope). According to the verses of the Quran, roads and pathways are always open and numerous, and considering them closed, which is a kind of disappointment with the divine mercy, is one of the greatest sins.

\section{"و مَن يقنط مِن رحمة ربه الا الضالّون}

"And who despairs of the mercy of his Lord, but such as go astray?" (Al-Hijr / 56).

According to verse 88 of Surah Al-Qasas, as there is no major concept separate from God in the Quran, the concept of life is based on a purely devotional goal, to replace God on earth (Baqara / 30). Thus, agency thinking is a factor or motivation that increases a person's desire and increases his faith and mental energy to achieve this goal, the divine encounter or reaching heaven and the blessings of the Hereafter. Its pathways are the righteous deeds in general, doing all the things that bring pleasure to God and his Prophet, along with sincerity and avoidance of polytheism (Kahf / 110). On the other hand, in the Quranic view, there is a direct relationship between motives and paths to achieve the goal. Thus, the more the desire to meet God or receive 
his mercy increases in human, the more righteous deeds he performs:

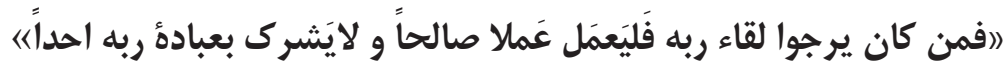

"Whoever expects to meet his Lord, let him work righteousness, and, in the worship of his Lord, admit no one as partner." (Kahf. 110)

Moreover, whenever the righteous deeds of a person increase, the hope of achieving the goal increases in him and his desire increases:

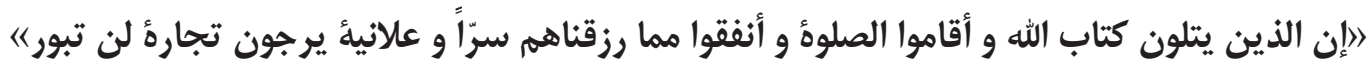

“Those who rehearse the Book of Allah, establish regular Prayer, and spend

[in Charity] out of what We have provided for them, secretly and openly, hope for a commerce that will never fail:" (Fatir, 29)

\section{Resilience constructs in positive psychology}

Resilience is one of the constructs in the field of psychological research with a great status, especially in the field of health psychology; family psychology, developmental psychology, and mental health so that the number of studies related to this construct increases (Campbell $\square$ Sills \& Stein, 2007). In simple terms, resilience is successful adaptation despite the threat and adverse environmental conditions where people live. Indeed, resilience is a positive adaptation in response to adverse conditions (Masten \& Reed, 2002). Resilience is not just passive resistance to harm or threatening conditions, but the resilient person is an active participant and builder of his or her environment. Resilience is defined as an individual's ability to balance bio-psycho-psychological balance in the face of risky situations (Connor \& Davidson, 2003) and a type of self-healing that is associated with positive emotional, cognitive, and cognitive consequences (Masten \& Reed, 2002; Ungar, 2008). It cannot be seen as recovery because in recovery, the person experiences negative consequences and emotional problems (Bonanno, 2004). According to Perkins and Jones (2004), resilience is characterized by a person's response to stressful life events or constant exposure to stress (lie war and sexual exploitation). Resilience is defined as a person's self-confidence in overcoming stress, having coping skills, self-esteem, emotional stability, and personal characteristics that increase social support from others. This construct is one of the factors preventing psychological problems among young people and adolescents, protecting them from the psychological effects of problematic events. Resilience is a factor that helps people cope with difficult and stressful life situations (Connor \& Davidson, 2003), increases the ability to adapt to pain, and increases the quality of life (Castro-Olivo et al., 2013). Resilience refers to the dynamic process of positive adaptation to bitter experiences (Luthar, Cicchetti, \& Becker, 2000) and refers to something beyond surviving the stresses and hardships of life (Bonanno, 2004). There are two categories of studies in the field of resilience: one group discusses the determinants of resilience and the characteristics of resilient people, and the second puts understanding of the resilience process on its agenda.

\section{Resilience construct in the Holy Quran}

In the Holy Quran, the three words "Sabr," "Helm," and "Esteghamat" are the closest words to the concept of resilience. Resilience means "the ability to return to the original state after curvature," and resilient is the one who can adapt to the situation with positive emotions, and cognitive interaction and reach the initial balance in challenging situations. Moreover, in the characteristics of resilient people in the Quran, characteristics such as "optimism and positive thinking, sense of solidarity, self-control, rational performance" are significant. 
Lexically, the word "Esteghamat" (endurance) is more closely related to resilience, but in the Quran, the word "Sabr" (patience) is more used and relevant to the subject of resilience. Although the word "Helm" (patience) does not fit well with the concept of resilience in the Quran, "Helm and Sabr" are the prelude to resilience according to the Quranic teachings, meaning that if one is free of these two attributes, one can never achieve the desired resilience. To the Quran, perseverance is the most important step to achieve resilience. Thus, the one who perseveres has enough patience.

Resilience is of the constructs that affect mental health and well-being that the Quran emphasizes on its creation and increase. Belief in God and having a monotheistic vision, contemplation on the history of the prophets, and the belief in the resurrection and the Day of Judgment are among the Quranic belief strategies in creating and strengthening resilience in humans. As God says in verses 155 and 156 of Surah Baqara: "Be sure we shall test you with something of fear and hunger, some loss in goods or lives or the fruits [of your toil], but give glad tidings to those who patiently persevere, Who say when afflicted with calamity: "To Allah We belong, and to Him is our return." (ibid) Those who, when a calamity befalls them, say, "We belong to God, and to Him we shall return." This verse considers the monotheistic worldview of the believers as the reason for their patience against adversity. God also considers contemplation in the story of Job (AS) as a means of strengthening the power of patience and endurance against difficulties by the believers. Thus, he refers to this story so that the wise may learn a lesson and use it to create and strengthen patience (pp. 41-44). Moreover, in verse 55 of Surah Ghafar, attention to the story and fate of Prophet Moses (pbuh) in the fight against the Pharaohs is considered as a base for patience for the Prophet (pbuh) and the believers. The belief in the resurrection and the Day of Judgment is another way of the Quran in creating and increasing patience. God says:

"Nay, seek [Allah's] help with patient perseverance and prayer: It is indeed hard, except to those who bring a lowly spirit,- Who bear in mind the certainty that they are to meet their Lord, and that they are to return to Him.” Baqara, 45-46

Accordingly, God has mentioned the belief in resurrection as the reason for the patience of Talut's troops against the enemy:

"When Talut set forth with the armies, he said: "Allah will test you at the stream: if any drinks of its water, He goes not with my army: Only those who taste not of it go with me: A mere sip out of the hand is excused." but they all drank of it, except a few. When they crossed the river,- He and the faithful ones with him,- they said: "This day We cannot cope with Goliath and his forces." but those who were convinced that they must meet Allah, said: "How oft, by Allah's will, Hath a small” Baqara, 249

Besides cognitive and doctrinal solutions, the Quran suggests some behavioral strategies to build and strengthen patience, one of which is "Infagh" (charity). God says:

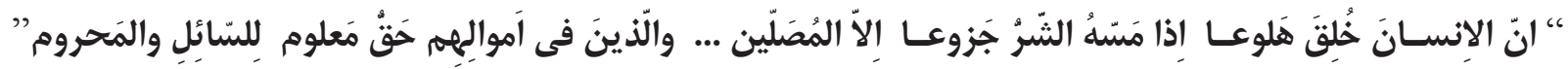

“Truly man was created very impatient;- 20. Fretful when evil touches him; 21. And niggardly when good reaches him;- 22. Not so those devoted to Prayer;- 23. Those who remain steadfast to their prayer; 24. And those in whose wealth is a recognised right." (Maarij, 19-24).

Vigil is one of the grounds for patience by the command of God, considered in verse 130 of Surah Taha and verses 24 to 26 of Surah Insan. The one who gets up for night prayers increases his capacity to resist difficulties and provides a suitable bed for him to resist the pressures of a whim. Moreover, God considers trustwor- 
thiness as one of the causes of patience in the face of evil and says:

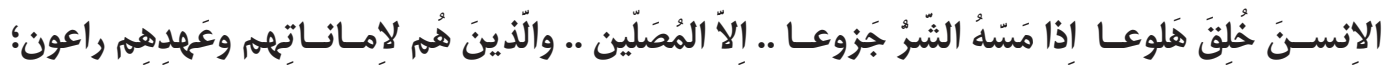

"Truly man was created very impatient;- Fretful when evil touches him; And niggardly when good reaches him;- Not so those devoted to Prayer;- Those who remain steadfast to their prayer; And those in whose wealth is a recognized right. For the [needy] who asks and him who is prevented [for some reason from asking]; And those who hold to the truth of the Day of Judgment; And those who fear the displeasure of their Lord,- For their Lord's displeasure is the opposite of Peace and Tranquillity;- And those who guard their chastity, Except with their wives and the [captives] whom their right hands possess,- for [then] they are not to be blamed, But those who trespass beyond this are transgressors;- And those who respect their trusts and covenants;" (Maarij / 19-32)

Forgiveness of sins is another solution of the Quran to create and strengthen patience. According to the verses of the Quran, forgiveness has many functions, which can include repelling calamity before coming, eliminating calamity, and gaining benefits and blessings. According to the teachings of revelation, the believer must always seek forgiveness, and if there were no forgiveness, humans would be in all kinds of problems and calamities. According to the Quran, just as the existence of the Prophet (PBUH) prevents the descent of calamity, so does forgiveness prevent the descent of calamity. As he says, as long as you (the Prophet) are among them, God will not punish them, and when they ask for forgiveness (Anfal / 33). Elsewhere, God refers to the connection between foregiveness and patience and says:

\section{فَاصبر ... واستَغِفر لِذَنبَِ}

So wait and ask for forgiveness for the consequences of your behavior (Ghafar / 55).

Asking for forgiveness helps us be safe in the shelter of God from the effects and consequences and the desired and unwanted consequences of our actions.

Knowledge and understanding of the philosophy of events is a ground for patience, too, according to the Quranic verses. This means that as far as a person is unaware of events, he naturally loses his temper and deals with the problem with a state of anger, rage and emotional excitement. Regarding this, God warns Prophet Moses (pbuh) in the words of Prophet Khidr (pbuh) that because of lack of knowledge and ignorance, he will not be able to be patient with actions and will react emotionally to actions quickly. Thus, he cannot be patient with events and speeches:

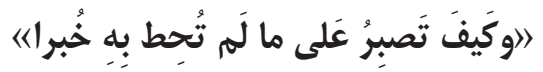

"And how canst thou have patience about things about which thy understanding is not complete?" (Kahf / 68) Hence, to create patience or increase the threshold of tolerance so that we do not have an emotional and nervous reaction to events and happenings, we must have knowledge and awareness about the subject, action, and incident. Moreover, in some verses of the Quran, God has considered the knowledge of the fate of the past as a factor of patience in the face of opposition and hostility, so that the Prophet (pbuh) can be patient and not impatient and disgusted against the actions and events that he encounters while preaching. God has introduced the awareness of the Prophet (PBUH) in the form of unseen news as a factor for his patience and said:

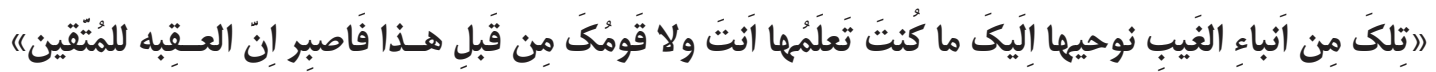

Such are some of the stories of the unseen, which we have revealed untothee: before this, neither thou nor thy people knew them. So persevere patiently: for the End is for those who are righteous (Hud, 49).

God considers the knowledge of divine laws and traditions as the base for patience and endurance in hardships and strongly and asks people to be aware of the divine laws and traditions. To be aware of these traditions, one 
can use the Quran itself, as in the verses of the Quran, the traditions and laws that govern the soul, society and the world are stated. Among the divine traditions is the tradition of procrastination and extraction. Awareness of this tradition allows us to be patient against the pressures of infidels and the threat of enemies, as we know that God will eventually punish them as he has destroyed many tribes. God also refers to the tradition of a definite term for individuals and tribes and introduces it as the base for creating or increasing patience (Taha / 128-130).

\section{Forgiveness construct in positive psychology}

Forgiveness in psychology is defined as personal development, moving from a position of hatred and anger to reducing anger and not taking revenge on the wrongdoer (Baharudin, Sumari, \& Hamdani, 2019). Simply put, forgiveness in psychology means "not taking revenge on the wrongdoer." Forgiveness is a moral virtue done against the faults of others and can be taught (Coyle \& Enright, 1997). Although revenge is a natural human response to the mistakes of others (Myerberg, 2011), forgiveness is the highway to mental health (Gismero-González et al., 2020).

Much discussion has existed in defining forgiveness (Coyle \& Enright, 1997). Toussaint Webb argues that forgiveness should be conceptualized as a multidimensional construct of emotion, behavior, and cognition, emphasizing the significance of different goals (like person, others, and God) and ways of forgiving (like expressing feelings and seeking) (Webb, Toussaint, \& Conway-Williams, 2012). Coyle and Enright (1997) consider forgiveness as a process of overlooking the faults of others, either motivated by inner peace or improved relationships with the offender or to perform value behavior and has the consequences of getting rid of negative feelings about the offender, and overcoming resentment, evil and avoidance of anger, distance, separation, and revenge against the wrongdoer.

It is necessary to examine the concept of error to understand the construct of forgiveness in psychology better. Mistakes are events that everyone considers contrary to their expectations and assumptions, others and the world. When the people experience mistakes, they typically develop negative thoughts like "This mistake has ruined my life," emotions like "anger" or behaviors like "revenge" that relate to the type of mistake and how they react (cognitive, emotional, or behavioral) is up to the offender. Thus, the giver's response refers to a set of thoughts, emotions, or behaviors that he or she expresses toward wrongdoers, errors, and the consequences associated with errors (Worthington Jr, 2007).

When people forgive, they accept that a mistake has occurred and then re-evaluate the error and the wrongdoer through cognitive, emotional, or behavioral processing. This means that forgiving person re-evaluates the wrongdoer in a new way (Thompson et al., 2005). In forgiveness, negative motives like revenge against the wrongdoer change to positive motives of reconciliation and goodwill. In other words, the forgiveness of renewed motivations is related to the motivations of reconciliation and goodwill (Thompson et al., 2005).

Many scholars have suggested that the forgiver should increase feelings of benevolence or even love for the wrongdoer as well (McCullough, Pargament, \& Thoresen, 2000; Worthington Jr, 2007). However, most scholars argue that positive feelings or love for the wrongdoer is not essential components of forgiveness (Tangney, Boone, \& Dearing, 2005).

Various models have been proposed by researchers in examining the process of forgiveness (Gordon, 2003; Harris \& Thoresen, 2005; Koutsos, Wertheim, \& Kornblum, 2008). Enright, Gassin, and Wu (1992) approach defines forgiveness as a psychological response that includes six psychological components: lack of affection, 
negative judgment, and behavior toward the offender, and the presence of positive emotion, judgment, and positive behavior toward the wrongdoer. Worthington's approach defines forgiveness as the displacement of emotions like hatred, bitterness, resentment, enmity, anger, and fear with emotions of positive concepts like love, empathy, compassion, or empathy (Worthington Jr, 2007).

Rye's approach defines forgiveness as releasing negative emotion (like hostility), negative cognition (like revenge thoughts), and negative behavior (like verbal aggression) in response to perceived injustice (Rye \& Pargament, 2002). Luskin's and other researchers' approaches introduce forgiveness as a calming intrapersonal process that promotes growth (Luskin, 2006). The forgiver person knows that if he forgives, he will experience less personal resentment, will be less to blame and can offer understanding to the wrongdoer.

Enright and the Human Development Studies Group argue that the forgiveness process pattern has 20 behavioral and cognitive processes that occur when a wrongdoer is forgiven. They consider forgiveness as an emotional, cognitive, and behavioral integration that together evokes an ethical response that is forgiveness (Rainey, Readdick, \& Thyer, 2012).

Forgiveness depends on different factors like situational factors (the intention of the offender, recidivism, severity of consequences, apology of the offender, compensation), communication factors (the identity of the offender and his closeness to the victim, his hierarchical status, attitude towards / after the commission of crime, environmental pressures) and personality factors (Myerberg, 2011). Forgiveness can bring about peace and reconciliation, which can play a role in the transmission of justice (Luskin, 2006). Forgiveness affects well-being and mental health and can be used as a tool in the treatment of mental disorders (Bono, McCullough, \& Root, 2008). There is a significant relationship between forgiveness, perfectionism, intimacy, and life satisfaction (Kim, Johnson, \& Ripley, 2011). In one example, students who procrastinated in reading a lesson were less likely to procrastinate on subsequent exams when faced forgiveness (Wohl, Pychyl, \& Bennett, 2010). Brose, Rye, Lutz-Zois, and Ross (2005) showed that forgiving others is positively associated with extraversion, and introversion is a deterrent to forgiveness. Those who are introverted are less likely to be forgiven by others. Openness to experience is a cultivating trait of forgiveness. However, the studies could not find the relationship between openness and forgiving others..

Forgiveness affects well-being and mental health and can be used as a tool in the treatment of mental disorders (Toussaint \& Webb, 2005). There is a significant relationship between forgiveness, perfectionism, intimacy, and life satisfaction (Kim et al., 2011).

\section{Forgiveness construct in the Quran}

"Aa," "Safh," and "Helm are of the Quranic words that can be related to forgiveness in psychology. The word "Afv" means "not taking revenge for the wrongs of others by a person capable of revenge", which is the closest word to the meaning of the word "forgiveness" in psychology. Ragheb Esfahani says foregiveness means intending to take something; "Afah wa Atifah" meaning thay he intended to get what he has. Forgiveness of sin means the intention to remove sin (Ragheb Isfahani, 1412, Zeyl Risheh Affa). Forgiveness means, "To give up and leave alone." Thus, "Aff anha" (forgiveness) is used to show the renunciation of the punishment of sin. Thus, its common meaning is forgiveness and ignoring like

\section{》اعفا الله عما سلف و من عاد فينتقم الله منه《)}

Obey Allah, and obey the Apostle, and beware (of evil): If ye do turn back, know ye that it is Our Apostle's duty to proclaim (the Message) in the clearest manner. (Maida, 95) 
or

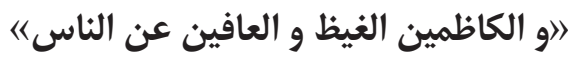

Who restrain anger, and pardon [all] men;- for Allah loves those who do good;-

(Al-i-Imran, 134)

Since it is constantly transliterated in the Quran with "An", it must be defined as forgiveness (Fazlullah, 2007). Allameh Tabatabai states the following verse 219 of Surah Baqara, after quoting Ragheb Isfahani, who argues that forgiveness means intending to do something: Verbal favors have caused this word to be used in many meanings like forgiving sin, erasing the effect and the middle ground in charity.

Studying the Quranic verses of forgiveness shows that the Quran has used cognitive (doctrinal) and behavioral strategies to create and increase this construct and encourage humans to use it. Belief in the monotheism and oneness of God is one of the Quranic ways of belief that can pave the way for forgiveness, as God has primarily introduced himself as forgiving. Attention to the point that God has attributed the attribute of forgiveness to himself in the Quran can be the base for this attribute in humans. The use of the adjectives "Afv" and "Ghafour" about God in the Quran can create and strengthen the construct of forgiveness in humans. The human tries to create and cultivate the attributes of God in him to approach the position of the caliphate of God. Thus, strengthening the doctrinal base of monotheism can be considered as a way of the Quran in creating the construct of forgiveness in humans. In verse 149 of Surah Nisaa, while advising forgiveness of evil, God has introduced himself as the forgiver.

״إن تبدوا خيراً أو تُخفوه أو تعفوا عن سوءٍ فإن الله كانَ عفوّاً قديراً)

For these, there is hope that Allah will forgive: For Allah doth blot out [sins] and forgive again and again (also Nisaa, 99)

Attention to the divine power and the fact that God himself reprimands the people in the world less with his justice, but confronts them with forgiveness and forgives them and many of their sins and mistakes, showing that the principle of forgiveness and benevolence is a good thing and a divine virtue. Verse 187 of Surah Baqara states God's forgiveness for the sins of his servants seeking their repentance. Moreover, verse 22 of Surah Noor states that human's interest in divine forgiveness and gaining his attention is a ground for forgiveness and forgiveness of the mistakes of others.

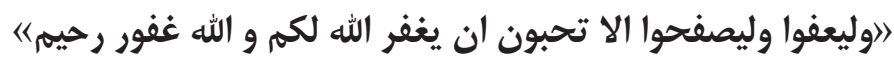

"Let not those among you who are endued with grace and amplitude of means

resolve by oath against helping their kinsmen, those in want, and those who have left their homes in Allah's cause: let them forgive and overlook, do you not wish that Allah should forgive you? For Allah is Oft-Forgiving, Most Merciful" (Nur / 22).

In verse 109 of Surah Baqara, it is stated that paying attention to the absolute power of God paves the way for forgiveness of the wrongdoings of others. Moreover, of the examples of God's forgiveness are worship calf and the wickedness of the people of Prophet Moses (pbuh) and God's forgiveness (Baqara, 52; Nisaa, 153). Remembering the story of the prophets and their forgiveness towards those who deserved revenge is in line with the Quranic doctrinal strategies in creating and increasing forgiveness. Modeling the prophets and saints in the issue of forgiveness, originating from man's belief in the principle of prophecy, is the proposed solution of the Quran in creating and increasing forgiveness. Prophet Yusuf (AS) did not revenge against his brothers. 《قال لا ثثريب عليكم اليوم يغفر الله لكم...»

He said: "This day let no reproach be [cast] on you: Allah will forgive you, and He is the Most Merciful of 
those who show mercy!" (Yusuf, 92)

Telling the stories of the prophets in using the construct of forgiveness instead of revenge, originating from the belief of man in the principle of prophecy, is another way of the Quran in creating the construct of forgiveness in humans. The Prophet (pbuh) forgives many deeds and mistakes of the People of the Book (Maida, 15). Belief in the resurrection and the Day of Judgment is another way for the Quran to create and increase forgiveness. In verse 85 of Surah Hajar, God says belief in resurrection and resurrection and purposefulness of creation and the inevitability of accountability and calculation is the base for forgiveness of others. In addition, strengthening spiritualism can institutionalize the culture of forgiveness, which cannot be achieved except by strengthening the spirit of the Hereafter. On the other hand, attention to the consequences of forgiveness is another solution of the Quran in creating and strengthening the construct of forgiveness. God considers the forgiveness of others as the base for enjoying his forgiveness (Nur / 22) and divine reward (Shura / 40). The realization of some of these eternal consequences and promises of forgiveness needs belief in the resurrection and the afterlife.

Behavioral strategies can be effective in creating and increasing the construct of forgiveness in people who have been considered by the Quran, advising to forgive the dowry during divorce (Baqara, 237), ignoring the evils of others (Shura, 40).

Awareness of the effects and blessings of forgiveness is another way to create and increase the construct of forgiveness in people, and the Quran, while stating some of these effects, has encouraged humans. According to the verses of the Quran, forgiveness causes one to enjoy the status of the patient (Nahl, 126), the pious (Baqara, 237), and the virtuous (Imran, 134; Maida, 13). In addition, forgiveness has been introduced as the atonement for sins (Maida, 45) in the Quran and the reason for receiving a double reward (Qesas / 54).

\section{Conclusion}

The purpose of stating the constructs of hope, resilience, and forgiveness in positive psychology and the Quran is human evolution. Positive psychology is generally based on materialism, semantics, mundane issues and individualism by designing these constructs looks for human success in life and having positive emotions. However, based on human's beliefs and convictions towards God, the Prophet, and the Resurrection, the Quran tries to achieve human closeness to God and the position of the divine caliphate by designing these constructs. The studies on these constructs in positive psychology show that these constructs can be effective in human well-being, mental health, and reducing mental harm. Thus, the studies have mostly sought to discover the relationship between these constructs by reducing some harm like depression, anxiety, improving couples' personal relationships, and so on. Accordingly, these constructs are mostly used as therapeutic constructs and try to measure the effectiveness of training these constructs in the treatment of diseases. Therefore, positive psychology recommends the creation and increase of these constructs in the individual for human mental health. The Holy Quran has dealt with these three constructs from different angles. One of those is the effect that these three constructs can have on human development and his psychological well-being. Accordingly, the Quran has shown belief and behavioral strategies in all three constructs to create and increase them in the individual. Belief in monotheism, prophecy and resurrection are among the cognitive and doctrinal solutions of the Quran in this regard. Where the Quran states the name of God Almighty when inviting people to hope, resilience and forgiveness it talks of the practical life of the prophets and mentions the resurrection by mentioning their reward in the Hereafter. The context paves the way of these constructs and increases human 
awareness and knowledge of these constructs. A step that is considered in positive psychology at the beginning of treatment and psychologists try to draw the minds of their clients to this construct and, by mentioning human models, provide him with more knowledge and awareness about these constructs: the patterns in the teachings of the Quran, prophets, and saints. Moreover, the Quran suggests some behavioral strategies to increase and strengthen these constructs like night vigil, repentance and devotion to God, kindness, almsgiving, trustworthiness, forgiveness of sins, ignoring the evils of others, and so on. Thus, the Quran provides the grounds for the emergence and strengthening of these constructs in humans by cognitive-behavioral solutions. In positive psychology, these strategies are used to treat some diseases.

However, the difference here is that in the field of cognition, cognition of these constructs is obtained in a different way than through belief in religious principles like theology, prophecy, and resurrection. In behavioral sphere, the strategies are different because the solutions proposed by the Quran are consistent with the same beliefs and the positive psychology has ignored them.

The theory of hope in psychology is a cognitive-behavioral theory, as the clients correct their behaviors to achieve the goals through their knowledge. In the Quran, too, desirable hope has cognitive-behavioral aspects as God gives knowledge and awareness to human by expressing belief solutions and tries to correct his behaviors through behavioral solutions.

Instilling hope and increasing hope are the two main stages of hope therapy in psychology and the Quran. The Quran has stated the doctrinal strategies to induce hope and behavioral strategies to enhance it. According to the Quran, hope is achieved through faith and righteous deeds, as well as the avoidance of committing sins (Tauba / 71), as according to the Quran, true hope is what guides a person to strive and move. The desired and true hope is created in a person through faith in God and love for him strengthened through divine mercy and the reflection of his attributes in humans.

Additionally, the Quran has told hopeful stories in their lives to create the spirit of hope in human beings. As in the story of the battle of Uhud, he told the story of the battle of Badr to instill the spirit of hope in them referring to the despair of Muslims after seeing the enemy army (Imran, 123-127). On the other hand, it reminds the divine blessings in personal life (Fatir, 3). In psychology, the therapist tries to redefine his or her life to help clients understand the hope they have experienced in the past, to gain a more positive view of their future (Bahari, 2011).

The Quran leads him to believe in prophecy and resurrection for human hope-banding, and by advising him to follow the example of the prophets and saints as true hopefuls, tries to create a positive attitude towards death in the light of believing in the resurrection. In psychology, the therapist models hopeful thinking and behavior and enhance agency and pathway thinking in clients. Thus, in both the Quran and psychology, attention to the pattern leads to hope-banding, with the difference that the examples of role models in the vision of the Quran are the prophets and saints. Moreover, the Quran has attempted hope-banding strengthening the belief in the resurrection, and considers forgetting or denying the Hereafter as the most important cause of pathway despair, whereas the theory of hope in psychology is silent on this issue.

The dimensions of hope (goal thinking, pathway thinking, and agent thinking) interact with each other according to the theory of hope in positive psychology and the Quran. Setting important goals increases motivation and the motivations help find agency.

On the other hand, in both the areas of positive psychology and the Quran, hope means waiting to reach a goal, along with effort, except that science states beings and non-beings and has no value discussion in its discus- 
sions. Hence, in positive psychology, there is no desirable or undesirable hope, and humans need the school of revelation to find the answer to this question to distinguish true hope from false hope. Religion separates false hope from true ones and shows the way to reach true hopes for humans.

Resilience and forgiveness constructs have been proposed in positive psychology and the Quran for human evolution. In positive psychology, attention has been paid to teaching these constructs to clients with a therapeutic approach and a methodological-behavioral method. Additionally, by creating and increasing them in clients, it is tried to enhance their well-being and solve their problems. By offering doctrinal-behavioral solutions, the Quran pays attention to the creation and increase of these constructs in humans and helps them reach the position of the divine caliphate.

Funding: The author received no financial support for the research, authorship, and/or publication of this article.

\section{References}

The Holy Quran

Bahari, F. (2011). The fundamentals of hope and hope therapy: A guide to hope creation. Tehran: Danzhe.

Baharudin, D. F., Sumari, M., \& Hamdani, S. M. (2019). Shame Transformation Using an Islamic Psycho-Spiritual Approach for Malay Muslims Recovering from Substance Dependence. In The Bright Side of Shame (pp. 199-214): Springer.

Bandura, A. (1997). The anatomy of stages of change. American journal of health promotion: AJHP, 12(1), 8-10.

Bishop, S. R., Lau, M., Shapiro, S., Carlson, L., Anderson, N. D., Carmody, J., . . Velting, D. (2004). Mindfulness: A proposed operational definition. Clinical psychology: Science and practice, 11(3), 230-241.

Bonanno, G. A. (2004). Loss, trauma, and human resilience: Have we underestimated the human capacity to thrive after extremely aversive events? American Psychologist, 59(1), 20.

Bono, G., McCullough, M. E., \& Root, L. M. (2008). Forgiveness, feeling connected to others, and well-being: Two longitudinal studies. Personality and social psychology bulletin, 34(2), 182-195.

Brose, L. A., Rye, M. S., Lutz-Zois, C., \& Ross, S. R. (2005). Forgiveness and personality traits. Personality and Individual Differences, 39(1), 35-46.

Buchanan, K. E., \& Bardi, A. (2010). Acts of kindness and acts of novelty affect life satisfaction. The Journal of social psychology, 150(3), 235-237.

Campbell $\square$ Sills, L., \& Stein, M. B. (2007). Psychometric analysis and refinement of the connor-davidson resilience scale (CD $\square$ RISC): Validation of a 10 $\square$ item measure of resilience. Journal of Traumatic Stress: Official Publication of The International Society for Traumatic Stress Studies, 20(6), 1019-1028.

Castro-Olivo, S. M., Tran, O. K., Begum, G. F., Arellano, E. M., Garcia, N. M., \& Tung, C. Y. (2013). A comprehensive model for promoting resiliency and preventing violence in schools. Contemporary School Psychology: Formerly" The California School Psychologist", 17(1), 23-34.

Connor, K. M., \& Davidson, J. R. (2003). Development of a new resilience scale: The Connor $\square$ Davidson resilience scale (CD $\square$ RISC). Depression and anxiety, 18(2), 76-82.

Coyle, C. T., \& Enright, R. D. (1997). Forgiveness intervention with postabortion men. Journal of consulting and clinical psychology, 65(6), 1042. 
Csikszentmihalyi, M., Latter, P., \& Weinkauff Duranso, C. (2017). Running flow: Human Kinetics.

Csikszentmihalyi, M., \& Seligman, M. E. (2000). Positive psychology: An introduction. American Psychologist, 55(1), 5-14.

Diener, E., \& Lucas, R. E. (2000). Explaining differences in societal levels of happiness: Relative standards, need fulfillment, culture, and evaluation theory. Journal of Happiness Studies, 1(1), 41-78.

Enright, R. D., Gassin, E. A., \& Wu, C. R. (1992). Forgiveness: A developmental view. In (Vol. 21, pp. 99114): Taylor \& Francis.

Fazlullah, S. M. H. (2007). al-Malek publishing house, 1419 AD• Ghorashi, Ali Akbar. Qamas al-Quran. Tehran, Dar al-Kabul al-Islami, 1996. Qomi Mashhadi, Mohammad ibn Mohammad Reza."Kans Al-Daghaegh and Bahr al-Gharreb". Tehran, Printing and Publishing Organization of the. Islamic Studies, 75, 11-38.

Feldman, D. B., Rand, K. L., \& Kahle-Wrobleski, K. (2009). Hope and goal attainment: Testing a basic prediction of hope theory. Journal of Social and Clinical Psychology, 28(4), 479-497.

Fowler, R. D., Seligman, M. E., \& Koocher, G. P. (1999). The APA 1998 Annual Report. American Psychologist, 54(8), 537.

Fredrickson, B. L. (2003). The value of positive emotions: The emerging science of positive psychology is coming to understand why it's good to feel good. American scientist, 91(4), 330-335.

Gismero-González, E., Jódar, R., Martínez, M. P., Carrasco, M. J., Cagigal, V., \& Prieto-Ursúa, M. (2020). Interpersonal Offenses and Psychological Well-Being: The Mediating Role of Forgiveness. Journal of Happiness Studies, 21(1), 75-94.

Gordon, K. C. (2003). Forgiveness and marriage: Preliminary support for a measure based on a model of recovery from a marital betrayal. American Journal of Family Therapy, 31(3), 179-199.

Harris, A. H., \& Thoresen, C. E. (2005). Forgiveness, unforgiveness, health, and disease. Handbook of forgiveness, 321-334.

Harzer, C. (2016). The eudaimonics of human strengths: The relations between character strengths and well-being. In Handbook of eudaimonic well-being (pp. 307-322): Springer.

JahangiriZadeh, P., \& Khodabakhshi Koolaee, A. (2016). The relationship between self-concept, life satisfaction and hope among retired and housewife older adults' women. Journal of Gerontology, 1(1), 19-28.

James, S. L., \& Roby, J. L. (2019). Comparing reunified and residential care facility children's wellbeing in Ghana: The role of hope. Children and Youth Services Review, 96, 316-325.

Joseph, S., \& Linley, P. A. (2006). Growth following adversity: Theoretical perspectives and implications for clinical practice. Clinical psychology review, 26(8), 1041-1053.

Kim, L. M., Johnson, J. L., \& Ripley, J. (2011). A” Perfect” Storm: Perfectionism, Forgiveness, and Marital Satisfaction. Individual Differences Research, 9(4).

Koutsos, P., Wertheim, E. H., \& Kornblum, J. (2008). Paths to interpersonal forgiveness: The roles of personality, disposition to forgive and contextual factors in predicting forgiveness following a specific offence. Personality and Individual Differences, 44(2), 337-348.

Lopez, S. J., Pedrotti, J. T., \& Snyder, C. R. (2007). Positive psychology: The scientific and practical explorations of human. In: SAGE Publications, Inc.

Luskin, F. (2006). Forgive for good: KTEH \& Standford University.

Luthar, S. S., Cicchetti, D., \& Becker, B. (2000). Research on resilience: Response to commentaries. Child 
development, 71(3), 573-575.

Masten, A. S., \& Reed, M.-G. J. (2002). Resilience in development. Handbook of positive psychology, 74, 88.

McCullough, M. E., Pargament, K. I., \& Thoresen, C. E. (2000). Forgiveness: Theory, research, and practice: Guilford Press.

Myerberg, L. (2011). Forgiveness and Self-Regulation: Forgiveness as a Mechanism of Self-Regulation. An Ego-Depletion Model. Honors Thesis in Psychology University of Richmond,

Perkins, D. F., \& Jones, K. R. (2004). Risk behaviors and resiliency within physically abused adolescents. Child abuse \& neglect, 28(5), 547-563.

Rainey, C. A., Readdick, C. A., \& Thyer, B. A. (2012). Forgiveness-Based Group Therapy. Best Practices in Mental Health, 8(1), 29-51.

Rye, M. S., \& Pargament, K. I. (2002). Forgiveness and romantic relationships in college: Can it heal the wounded heart? Journal of Clinical Psychology, 58(4), 419-441.

Samavi, S. A., Najarpourian, S., \& Javdan, M. (2019). The effectiveness of group Hope therapy in labor pain and mental health of pregnant women. Psychological Reports, 122(6), 2063-2073.

Seligman, M. E. (2006). Learned optimism: How to change your mind and your life: Vintage.

Sheldon, K. M., \& King, L. (2001). Why positive psychology is necessary. American Psychologist, 56(3), 216.

Snyder, C. R. (1994). The psychology of hope: You can get there from here: Simon and Schuster.

Snyder, C. R. (2002). Hope theory: Rainbows in the mind. Psychological inquiry, 13(4), 249-275.

Snyder, C. R., Shorey, H. S., Cheavens, J., Pulvers, K. M., Adams III, V. H., \& Wiklund, C. (2002). Hope and academic success in college. Journal of Educational Psychology, 94(4), 820.

Tangney, J. P., Boone, A. L., \& Dearing, R. (2005). Forgiving the self: Conceptual issues and empirical findings. Handbook of forgiveness, 143-158.

Thompson, L. Y., Snyder, C. R., Hoffman, L., Michael, S. T., Rasmussen, H. N., Billings, L. S., . . Roberts, J. C. (2005). Dispositional forgiveness of self, others, and situations. Journal of personality, 73(2), 313-360.

Toussaint, L., \& Webb, J. R. (2005). Theoretical and empirical connections between forgiveness, mental health, and well-being. Handbook of forgiveness, 349-362.

Ungar, M. (2008). Resilience across cultures. The British Journal of Social Work, 38(2), 218-235.

Webb, J. R., Toussaint, L., \& Conway-Williams, E. (2012). Forgiveness and health: Psycho-spiritual integration and the promotion of better healthcare. Journal of Health Care Chaplaincy, 18(1-2), 57-73.

Wohl, M. J., Pychyl, T. A., \& Bennett, S. H. (2010). I forgive myself, now I can study: How self-forgiveness for procrastinating can reduce future procrastination. Personality and Individual Differences, 48(7), 803808.

Worthington Jr, E. L. (2007). Handbook of forgiveness: Routledge. 